\section{Prolonged aerial chase of Willow Grouse Lagopus lagopus by Common Raven Corvus corax}

\section{Göran Högstedt}

Department of Biology, University of Bergen, P.O. Box 7803, N-5020 Bergen, Norway

e-mail: Goran.Hogstedt@bio.uib.no

Abstract. Two vigorously fighting male Willow Grouse Lagopus lagopus were simultaneously attacked by a Common Raven Corvus corax and a Rough-legged Buzzard Buteo lagopus. The raven pursued one of the grouse over $900 \mathrm{~m}$; the chase ended when the grouse dived into dense willows. The two birds kept the same distance, meaning that the raven flew at roughly $75 \mathrm{~km} / \mathrm{h}$ (maximum level flight speed of Willow Grouse)

Common Ravens Corvus corax are opportunistic feeders, often scavenging carcasses of various-sized vertebrates. Only rarely do Common Ravens hunt down full-grown and healthy prey (Glutz von Blotzheim \& Bauer 1993). In this note I describe a persistent aerial pursuit of a Willow Grouse Lagopus lagopus by a Common Raven near Vardø $\left(70^{\circ} \mathrm{N}, 31^{\circ} \mathrm{E}\right)$, northern Norway.

The year 2007 was a peak rodent year with high densities of microtines, mainly root voles Microtus oeconomus. Willow Grouse also had a good reproduction this year, as judged by frequent observations and the fact that a nearby pair of Gyr Falcons Falco rusticolus fledged three young.

The 20th of June was a fine day $\left(5^{\circ} \mathrm{C}, \mathrm{NE} 4 \mathrm{~m} / \mathrm{s}\right.$, $25 \%$ cloud cover at 10 a.m.). Two Willow Grouse cocks were seen displaying and fighting some 300 $\mathrm{m}$ away. They wore mating plumage, i.e. largely white with brown head and neck. The grouse activity aroused simultaneous interest in a Rough-legged Buzzard Buteo lagopus and an adult Common Raven, both of which attacked the two grouse. One of the grouses disappeared quickly among the vegetation while the second took flight, eagerly pursued by the two predators. The buzzard was soon outflown, but the raven continued its pursuit, now at an altitude of approximately $50 \mathrm{~m}$. The two birds passed right above me and I could hear a powerful swishing sound from the raven's wings. Distance between the birds was roughly $50 \mathrm{~m}$ and remained constant for the entire flight of 900 $\mathrm{m}$, as measured from a map (1:50000). Unfortunately, the flight was not timed, but it was obvious that both birds performed maximally. According to Glutz von Blotzheim et al (1973, p. 89) grouse can fly at $75 \mathrm{~km} / \mathrm{h}$, while transport flight speed for the Common Raven is $45 \mathrm{~km} / \mathrm{h}$. There are no data for maximum speed of Common Ravens, but other corvids with transport speeds at $45 \mathrm{~km} / \mathrm{h}$ may attain level flight speeds at 72 (Rook Corvus frugilegus) and $80 \mathrm{~km} / \mathrm{h}$ (Alpine Chough Pyrrhocorax graculus), respectively (Glutz von Blotzheim \& Bauer1993).

After having passed several good sheltering places (stands of 1.0-1.5 m high willows Salix ssp), the grouse dived into one of them, closely followed by the raven. Within half a minute the raven flew up just to disappear at another place in the willows. The male grouse had a mixed plumage of white and brown and must therefore have been easily visible, but the dense vegetation made further pursuit difficult, and after a few minutes the exhausted raven spent several minutes resting.

Such persistent pursuit of apparently healthy prey by a raven has not been observed before, according to literature (Glutz von Blotzheim \& Bauer 1993, Ratcliffe 1997). Fighting grouse may inflict injury on their combatant and this may have caught the attention of the buzzard and the raven. If injured, the wound did not appear to hamper flight performance of the grouse, but may nevertheless have released an attack response in the two predators.

\section{REFERENCES}

Glutz von Blotzheim, U.N. \& Bauer, K.M. 1993. Handbuch der Vögel Mitteleuropas. Vol. 13/1. Aula-Verlag, Wiesbaden.

Glutz von Blotzheim, U.N., Bauer, K.M. \& Bezzel, E. 1973. Handbuch der Vögel Mitteleuropas. Vol. 5, Aula-Verlag, Wiesbaden.

Ratcliffe, D. 1997. The Raven. T. \& A.D. Poyser, London. Received 20 March 2014. Accepted 5 November 2014 